\title{
H. L. A. HART AND THE INVENTION OF LEGAL PHILOSOPHY
}

\author{
Dan PRIEL*
}

Resumen:

En este ensayo se plantea la idea de que en cierto modo la filosofía del derecho - al menos en la forma en que es entendida entre los filósofos analíticos del mundo angloparlante- es en gran medida una invención de H. L. A. Hart. Con la obra de Hart, en efecto, la búsqueda del concepto o naturaleza del derecho, se ha consolidado como un objeto de investigación independiente, que conscientemente pretende deslindarse de las cuestiones políticas o morales. Al definir el campo de estudio de la filosofia del derecho en este sentido, Hart no sólo se aparta del trabajo de Thomas Hobbes y de Jeremy Bentham, cuyos compromisos políticos son evidentes, sino también del proyecto aparentemente más cercano de John Austin. Después de señalar la diferencia entre los proyectos de Austin y de Hart, el autor pone en cuestión la dirección que ha tomado la filosofia del derecho al ser encabezada por Hart.

Palabras clave:

Jurisprudencia analítica, filosofia del derecho, positivismo jurídico, naturaleza del derecho, H. L. A. Hart.

* Assistant Professor, Osgoode Hall Law School. 


\section{DAN PRIEL}

\section{Abstract:}

In this essay I argue that in some sense legal philosophy, at least as the term is now understood among analytic jurisprudents in the Anglophone world, is to a large extent a creation of H. L. A. Hart's work. It is with him that the search for the concept or the nature of law was one established as an independent object of inquiry, that consciously tried to avoid moral or political questions. In framing the province of jurisprudence in this way Hart not only departed from the work of Thomas Hobbes and Jeremy Bentham, whose political commitments are clear, but also from the seemingly much closer enterprise of John Austin. After demonstrating this difference between Austin's enterprise and Hart's, I criticize the direction legal philosophy has taken following Hart's lead.

Keywords:

Analytical Jurisprudence, Legal Philosophy, Legal Positivism, Nature of Law, H. L. A. Hart. 


\title{
H. L. A. HART AND THE INVENTION OF LEGAL PHILOSOPHY
}

\author{
Summary: I. Introduction. II. Austin's Novelty. III. Hart's \\ Inversion. IV. The Invention of Legal Philosophy. \\ V. Conclusion: Hart's Faustian Bargain.
}

\section{INTRODUCTION}

In the course of a rather heated exchange in the pages of the Times Literary Supplement Leslie Green and Brian Leiter wrote: "no one holds the view Professor [Brian] Simpson ascribes to us, namely 'that legal philosophy as a serious subject was invented by Hart"." 1 Well, this is, more-or-less, the thesis I am going to defend here. This is not because I have not heard of Aristotle, Bentham, Cicero, Duguit, Ehrlich, Frank, Grotius, Hobbes, or Ihering. I have, in fact, written about the fact that much of the plight of contemporary jurisprudence is the result of how little attention is paid to the work of historical figures, who were often more original and interesting than the thinkers whose works legal philosophers have analyzed to dust. My point, rather, is that with Hart the English-speaking world has seen the creation of a new way of thinking about jurisprudence, and that in doing so he, in some sense, created a new subject. But whereas Green and Leiter think of pre-Hart jurisprudence as "a dilettantish pastime for law teachers and retired judges, an undisciplined jumble of history, speculative sociology, legal doctrine and party politics, [that] became [with Hart] a technical and rigorous branch of philosophy,"2 I see Hart's contribution to jurisprudence in much more negative terms.

1 Green, Leslie J. \& Brian, Leiter, Letter to the Editor, "H. L. A. Hart", Times Literary Supplement, April 15, 2005, p. 15.

2 Green, Leslie J. \& Brian, Leiter, Letter to the Editor, "H. L. A. Hart and 'The Concept of Law"', Times Literary Supplement, March 11, 2005, p. 15. By the way, it should not be forgotten that philosophy in general from the first half of the twentieth century often appears quite amateurish by today's standards. Look at old volumes of the leading philosophical journals from those years and much of what appears there seems insufficiently rigorous by today's standards. 
This essay is part of a larger attempt to assess Hart's impact on jurisprudence, and in particular that of his book The Concept of $\mathrm{Law}^{3}$ a book whose continued influence I find less of a cause for celebration than others. My view, one I will not defend here, is that Hart's substantive theory of law as articulated in The Concept of Law is largely a failure. In part it is because of the major issues Hart left out of the book, which I think are crucial for any successful theory of law; in part this is because on many important issues Hart does address, his views are not very clear; and in part it is because whenever he is clear, his explanations are almost invariably less than successful. The Concept of Law has the further demerit of seriously simplifying and misrepresenting the views of opposing views, which renders Hart's critiques of those views not very illuminating. Though many of the misrepresentations in Hart's account of the work of legal realists, natural lawyers, and even earlier legal positivists have by now been pointed out, there is no doubt that many have taken their first (and often last) impression of these schools of thought from Hart, something that did not bode well for the subject. True, The Concept of Law was meant as a student textbook, and this inevitably required some simplification at the expense of clarity of exposition. But what one finds in Hart's book are serious distortions of fundamental ideas of other legal theorists, some of which are still with us.

What then is Hart's major contribution? I think Hart's most lasting influence on the field is the one that is probably least often noticed, and that is the setting of the boundaries of what actually belongs in the subject. The domain of jurisprudence today is largely understood in the terms that were defined by Hart. Hart's legacy is best defined by what jurisprudence is - and, importantly, is not- taken to be

3 Hart, H. L. A., The Concept of Law, 2nd ed., Oxford, Clarendon Press, 1994. Further references to the book are made to Concept, parenthetically in the text. Citations throughout are to the (slightly differently paginated but otherwise identical) second edition. 
about. But Hart did not begin with a clean slate: as is clear to any reader of The Concept of Law, despite Hart's criticisms of Austin, Hart's own theory is built on Austinian foundations. The purpose of this essay is to describe how Hart determined the province of jurisprudence by subtly but fundamentally shifting the ideas he took from Austin.

\section{Austin's Novelty}

"Mr. Austin once said of himself, that if he had any special intellectual vocation, it was that of "untying knots." So said Mill of his former teacher. And as Mill added, this description fit Austin "very correctly". ${ }^{4}$ Indeed. With seemingly unbounded amounts of pedantry he sought to tell us what "positive law" is. This required clarity of mind and well-kept conceptual books, and at times it looks as though Austin cared for little else. Ad nauseum one reads him telling us what law (and other things) mean when they are "properly so called", "strictly so called", or when they are used "in the proper acceptation of the term". When it came to law, this required untying the knot that tied it to morality. This untying was not because there was no, substantively, necessary connection between the two. Austin never utters the expression "no necessary connection between law and morality", and his famous slogan "the existence of law is one thing, its merit or demerit is another," 5 does not come remotely close to confirming it. What he does say, in fact, is that "[t]he proper purpose or end of a sovereign political government or the purpose or end for which it ought to exist is the greatest possible advancement of human happiness" (Province, p. 242), and this claim, if true, arguably establishes some kind of connection between law and mo-

\footnotetext{
4 Mill, John Stuart, "Austin on Jurisprudence", The Collected Works of John Stuart Mill, Vol. 21, Toronto, University of Toronto Press, 1984, 167-205, p. 168 (first published 1863).

5 Austin, John, The Province of Jurisprudence Determined, Wilfrid E. Rumble ed., Cambridge, Cambridge University Press, 1995, p. 157 (first published 1832). Further references to this book will be made to Province parenthetically in the text.
} 
rality. On the other hand unlike contemporary legal philosophers Austin did not try to identify those features that all legal systems necessarily have in common. He explicitly limits his claims to the "ampler and maturer" legal systems, whatever the proper acceptation of that term may be. ${ }^{6}$

It is true that he says that "[w]ith the goodness and badness of laws ... [jurisprudence] has no immediate concern," ("Study", p. 350) but that is a methodological device needed, he thought, for the clarity of explanation. As he put it:

Of laws or Rules there are various classes. Now these classes ought to be carefully distinguished. For the confusion of them under a common name, and the consequent tendency to confound Law and Morals, is one most prolific source of jargon, darkness, and perplexity. By a careful analysis of leading terms, law is detached from morals, and the attention of the student of jurisprudence is confined to the distinctions and divisions which relate to law exclusively. ("Study", p. 355, emphasis added.)

Or in a different formulation:

The matter of jurisprudence is positive law .... But positive law ... is often confounded with objects to which it is related by resemblance, and with object to which it is related in the way of analogy: with objects which are also signified, properly and improperly, by the large and vague expression law. To obviate the difficulties springing from that confusion, I begin ... with determining the province of jurisprudence, or with distinguish the matter of jurisprudence from those various related objects trying to define the subject of which I intend to treat, before I endeavor to analyse its numerous and complicated parts (Province, p. 18).

To understand how Austin sought to keep law and morality separate in this sense, we need to see his position in the line of thinkers that begins with Hobbes and ends with

6 Austin, John, "On the Study of Jurisprudence", Lectures on Jurisprudence, London, Murray, Vol. 3, 1863, 349-75, p. 349. Further references to this essay will be made to "Study" parenthetically in the text. See also Austin, Province, p. 165. 
Hart and contemporary legal positivism. I think a key to understanding the way he offered a non-political account of sovereignty, departing in this respect from what one finds in the work of Hobbes, and also (and perhaps more surprisingly) Bentham.

Hobbes identifies the essence of a commonwealth with the existence of a person or body that "hath the use of so much Power and Strength conferred on his, that by terror therefore, he is inabled to conforme the wills of" all to maintain peace. This person "of whose Acts a great Multitude, by mutuall Covenants one with another, have made themselves every one the Author" is the sovereign. ${ }^{7}$ Immediately after these words come a chapter dedicated to enumerating the rights and limits on sovereign power. For this reason, even though Hobbes favors granting sovereigns very broad powers, his account of sovereignty is not tantamount simply to whomever happens to be in power (as long as he protects his subjects). It is part of the contractarian story Hobbes offers as the grounds of legitimate political authority.

Bentham is interesting as well. It is true that his account of political power as an observable "habit of, and disposition to obedience: habit, speaking with respect to past acts; disposition, with respect to future" 8 looks like the same sort of explanation that (as we shall see in a moment) was later found in Austin's work. This, however, was only part of what Bentham had to say on sovereignty, and much of it, went beyond observations. His theory of law is tied to an account of sovereignty, which in turn addressed both the question of normativity (how law can bind) and the question of legitimacy (the conditions under which it succeeds

7 Hobbes, Thomas, Leviathan, Richard Tuck ed., Cambridge, Cambridge University Press, 1996, pp. 120-21 (ch. 17) (first published 1651).

8 Bentham, Jeremy, A Fragment on Government, J. H. Burns \& H. L. A. Hart (eds.), Oxford, Oxford University Press, 1988, pp. 101-102 (§IV.35) (first published 1776). 
in binding). ${ }^{9}$ After embracing democracy relatively late in his life Bentham came to be believe that sovereignty should be vested in the people. But even before that his explanation of the normativity of law was grounded in the existence of a reciprocal relationship between ruler and ruled. This allowed him to distinguish between legislative (and executive) sovereignty and autocratic sovereignty on the basis of the question whether the sovereign power was exercised "by rule or without rule" ${ }^{10}$ For these reasons it is a mistake to think that for Bentham sovereignty was a matter of pure observation. Like Hobbes, his theory of law was part of a broader political theory, and his views on sovereignty must be understood as one ingredient within that bigger picture.

Now consider Austin: It is with him that we find the definition of sovereignty that has come to be associated with command theories of law. An "independent political society" is one that has a "sovereign": the two terms, says, Austin are "inseparably connected" (Province, p. 165). The marks of the sovereign are that "[t]he bulk of the given society are in a habit of obedience ... to a determinate and common superior" and that the person or body who is in that position "is not in a habit of obedience to a determinate human superior" (Province, p. 166). Thus, the definition of sovereignty has been decoupled from an account of legitimacy and has been rested on factual grounds. When read together with Austin's definition of law -a kind of command made by "political superiors to political inferiors" (Province, p. 18)the result is what might have been called, had others not

9 See Postema, Gerald J., Bentham and the Common Law Tradition, Oxford, Clarendon Press, 1986, pp. 232-37, 255, 260-62. Postema does not distinguish between normativity and legitimacy in the way I do in the text, but it is clear from his discussion that Bentham was concerned with both. For the distinction between the two and its significance to jurisprudence see Priel, Dan, "The Place of Legitimacy in Legal Theory", McGill Law Journal, Vol. 57, 2011, 1-35.

10 See Bentham, Jeremy, An Introduction to the Principles of Morals and Legislation, Oxford, Clarendon Press, 1996, p. 263 note 4 (first published 1780) for the complete discussion. 
claimed this title for themselves, the pure theory of law, ${ }^{11}$ as the link between sovereignty and lawmaking power has become conceptual: the sovereign is whomever makes commands that are habitually obeyed and does not obey others; and those habitually obeyed commands are laws.

While Austin clearly sought to offer a non-political theory of law, and in this regard, he does have an important role in the story of the birth of legal philosophy, his account was still a step away from what would happen a century later in Hart's account, because this conceptual link between law and political power allowed Austin to offer an unambiguous explanation of the normativity of law. There is an "inseparable connection" between command, duty, and sanction, he says (Province, p. 24). Laws are commands, made by political superiors, the latter being understood in terms of "might: the power of affecting others with evil or pain" (Province, p. 30, see also p. 282). Translated to the language of modern jurisprudence Austin offers a certain theory explaining what laws are through an account of obedience to commands. One feature of this view, already mentioned, is that he seeks to explain the normativity of law in a manner that is completely independent of political questions of legitimacy. The other, and the one which is of greater significance for my purposes, is that the identification of "valid" legal norms is dependent on, and secondary to, his account of norma- tivity. For Austin the explanation of law's normativity is not a puzzle that requires solving over and above his account of identifying legal norms; rather, it is the basis for identifying them and part of his theory of what law is.

11 For a comparison between Austin's and Kelsen's theories see Kelsen, Hans, "The Pure Theory of Law and Analytical Jurisprudence", Harvard Law Review, Vol. 55, 1941, 44-70, pp. 54-66. Some of the criticisms Kelsen directs at Austin's work anticipate similar points found in Hart, The Concept of Law, supra note 3.

Admittedly, Kelsen's theory is "purer" than Austin's and there is no doubt that Kelsen (to some extent via his influence on Hart and Raz) is relevant for a full picture of the state of contemporary analytic jurisprudence today. That, however, is a question for another day. 
Austin defines "positive" laws - laws that "flow from human sources" (Province, p. 110) - as a species of commands. A command is then defined as an "intimat[ion of] a wish that [one] shall do or forbear from some act" and that intimation comes "with an evil in case [one] compl[ies] not with [the] wish" (Province, p. 21). The direct link between obligation and (threat of) sanction is clear when Austin discusses the question whether obligation exists whether the "magnitude of the eventual evil" matters for the question of obligation. Austin replies in the negative: "The sanction, if you will, is feeble or insufficient; but still there is a sanction, and, therefore, a duty and a command" (Province, p. 23, emphasis in original). ${ }^{12}$ There is sanction and therefore there is obligation.

In Austin's account there is no puzzle in understanding in what way law creates obligations, because the very definition of law seeks to remove all mystery from the matter. Thus, while Austin famously denied that an unjust law is not law, 13 his account implied that for him a non-threatening law is not law.

This is a crucial point in Austin's account: what counts as law is identified by appealing to an account of legal obligation. One thing this point helps us see and better understand is a feature of Austin's ideas that has come under considerable attack, namely the link between obligation and sanction. What we now see, however, is that this criticism is based on a misunderstanding of the way Austin understands the relationship between validity (law) and normativity (coercion). As we shall see in a moment, Hart

12 See also Province, p. 118: "Every duty properly so called supposes a command by which it is created. For every sanction properly so called is an eventual evil annexed to a command. And duty properly so called is obnoxiousness to evils of the kind".

13 "Suppose an act innocuous, or positively beneficial, be prohibited by the sovereign under the penalty of death; if I commit this act, I shall be tried and condemned, and if I object to the sentence, that it is contrary to the law of God, who has commanded that human lawgivers shall not prohibit acts which have no evil consequences, the Court of Justice will demonstrate the inconclusiveness of my reasoning by hanging me up" (Province, p. 158). 
understands the relationship between the two in a very different way (he does not identify laws through an account of normativity), which is why he concluded that their connection was contingent.

\section{HART'S INVERSION}

The conventional wisdom is that Hart demolished Austin's most important ideas. And up to a point, this is true. But what must not be forgotten when reading Hart's criticism of Austin is the he chose Austin as the subject of his criticism because he thought there were elements in them he could use to develop his own ideas. For this reason what is interesting is not so much Hart's critique of Austin, but the extent to which Hart followed Austin (cf. Hart, p. vii), the extent to which he adopted Austin's general approach - his demarcation of jurisprudence- without really arguing for it. After all, Austin's was not the only way of thinking about jurisprudence, and though he was popular and appeared in many of the books Hart hated so much, the books "form which one learns what other books contain" (Concept, p. vii), he was not the only one featured in these books and was far from being universally admired. ${ }^{14}$

Building on Austin, then, was not forced upon Hart. The reason Hart chose to do that was because, consciously or not, he felt a certain affinity with Austin's work: part of it must have been their shared concern for intellectual tidiness and clear-headedness, ${ }^{15}$ and another with the absence

14 In fact, many of the criticisms of Austin now associated with Hart were made by others many years earlier. See generally Rumble, Wilfrid E., Doing Austin Justice: The Reception of John Austin's Philosophy of Law in Nineteenth-Century England, London, Continuum, 2005, pp. 225-41: "One of the most remarkable features of the nineteenth-century reception of Austin's work is the significant extent to which is foreshadows H. L. A. Hart's highly influential criticisms of Austin" (quote at 225).

15 See Hart, H. L. A., "Positivism and the Separation of Law and Morals", Harvard Law Review, vol. 71, 1958, 593-629, pp. 593-94; see also Hart, H. L. A., "A View of America", Listener, Vol. 59, 1958, 89-90, p. 90; cf. White, Alan R., "Austin as a Philosophical Analyst" Archiv für Rechts- und Sozialphilosophie, Vol. 64, 1978, 379-399, for the suggestion that Austin could be considered an early proponent of "analytic" (here: ordinary language) philosophy. 
of Hart pejoratively called "metaphysics" in Austin's work. And so, not surprisingly, Hart's account appears, at first (and second) look, quite similar to Austin's. After all, even in the "official" story as told by Hart himself Austin's account contained several major deficiencies, ${ }^{16}$ which, once corrected, resulted in Hart's account. Most fundamentally, Hart took from Austin the separation of jurisprudence from political theory, something one does not find in the major contributions to jurisprudence by other philosophers now called "legal positivists".

Even though in all this Hart is closer to Austin than one would think from the space he dedicates to critiquing him, there is a different sense, one that to my knowledge has not been acknowledged, in which Hart did depart from Austin's approach. We have seen already that for Austin to understand what law is is fundamentally to understand how it obligates; as argued above, for him it is from understanding how law obligates that one can learn how to identify individual ("valid") legal norms. For Hart, by contrast, the answer to the question what is law is different. Indeed, in a sense Hart answers it in exactly the opposite way than Austin does. If Austin starts with explaining the sense in which laws create obligations and identifies "valid" legal norms on the basis of that, Hart starts with validity and then constructs from his account of validity an explanation of law's normativity. Indeed, it is probably the structure of his argument that explains why some readers doubted he even had an account of law's normativity. Michael Moore, for example, has argued that Hart was not concerned with the question when people have a legal obligation, but only with the

16 I will not deal here with the question whether Hart described Austin accurately. There are those who have strongly argued that he has not. See, in particular, Moles, Robert N., Definition and Rule in Legal Theory: A Reassessment of H. L. A. Hart and the Positivist Tradition, Oxford, Blackwell, 1987, especially ch. 2. There have also been those who have argued that Austin's account has the resources to address many of the charges raised by Hart. See Hardin, Russell, "Sanction and Obligation," Monist, Vol. 68, 1985, 403-18; Schauer, Frederick, "Was Austin Right After All? On the Role of Sanctions in a Theory of Law", Ratio Juris, Vol. 23, 2010, 1-21. I do not take a stand on this issue here as well. 
question when people put believe they have one. ${ }^{17}$ This account fits Hart's claim to be engaged in "descriptive sociology" (Concept, p. vi), but it comes at a high cost: this is descriptive sociology of the useless kind. It is not based on anything that would be remotely acceptable as evidence for a social scientific explanation: no interviews, questionnaires, collection of data or anything that could justify the claims Hart is making, if understood in these terms.

Therefore, the alternative reading, viz. that Hart's practice theory of rules is an account of normativity, looks more fruitful, or at least more charitable. However, at first it seems equally unpromising. If taken as a philosophical "elucidation" of legal obligation it seems to say, more or less, that people are under a social obligation when they believe they are under social obligation. And the problem with this view is that, as Stephen Perry once put it bluntly, "believing does not make it so". 18

In fact, however, we can discern a more elaborate account in The Concept of Law. For Hart, at a minimum, $A$ is under a legal obligation if

(1) there are relevant others who treat certain sources as a source of prescriptions;

(2) the relevant others have power and they use it to ensure that the prescriptions contained in the sources are generally obeyed (Concept, pp. 103-04);19 and

17 Moore, Michael S., Educating Oneself in Public: Critical Essays in Jurisprudence, Oxford, Oxford University Press, 2000, p. 85: "Hart is ... giving us a sociology of ethics. He is analysing when people regard themselves as bound by prescriptive rules, and more particular, when people regard themselves as bound by the social rules of obligations".

18 Perry, Stephen R., "Interpretation and Methodology in Legal Theory", in Andrei Marmor (ed.), Law and Interpretation: Essays in Legal Philosophy, Oxford, Clarendon Press, 1995, 97-135, p. 122.

19 Why the strong demand for power that is used? Because the most minimal case of a legal system according to Hart is one in which the As only obey the law because it creates threats. Hart claims that as a conceptual truth these are cases of a legal system. As he puts it "those rules of behaviour which are valid according to the system's ultimate criteria of validity must be generally obeyed.... [This] condition is the only one private citizens need satisfy: they may obey each 'for his part only' and from any motive whatever" (Concept, p. 116). For the difficulties this 
(3) those sources contain prescriptions directed at $A$.

There are familiar problems of circularity here (the others have to be what I called "relevant", and they are relevant in the sense that they are legal officials). I set them aside here. What matters is that what gets the legal system going, what separates a set of directives from a legal system (both words are important here: it is a system of laws) is the existence of a certain attitude among the officials. But with regard to the officials, their obligation, their "rule of recognition" consists of nothing more than the fact that they think they are under a certain obligation.

Is this sufficient for explaining law's normativity? Let us spell out the argument: Hart's claim is that one can be under a legal obligation when one treats the law as a threat to be avoided, and someone else treats law as reason for action. Is this not simply people believing that they are under an obligation? I think Hart's response to this question would be: "That's all there is to it. To look for something more than that, for anything deeper, is to maintain remnants of the old 'metaphysical' worldview of natural law". Now, notice that once you have accepted Hart's notion of validity, you have ipso facto understood his sense of the normativity of law. For a legal norm to be "valid" means for it to exist, and for it to exist means for it to be obligatory in this sense. It is worth noting that Hart wrote in the Postscript that his account aimed "to give an explanatory and clarifying account of law as a complex social and political institution with a rule-governed (and in that sense "normative) aspect" (Concept, p. 239, emphasis added). Being "normative" is nothing more than being "rule-governed", and being rule-governed is exactly Hart's account of law as union of primary and secondary rules. 
On this view if you are looking for more, you are committing a "category mistake". Gilbert Ryle, who coined this term used the example of the visitor to Oxford who, after seeing the colleges, academic departments, libraries, administrative offices and so on still asks, "But where is the university?" The answer, says, Ryle, is that once you have seen all that the visitor saw "the University has been seen". ${ }^{20}$ In effect, Hart charges the critic who looks for more than this, to be making exactly the same mistake. Once you have understood Hart's account of law as a union of primary and secondary rules, the normativity of law has been seen. ${ }^{21}$

Why, you may wonder, does all this matter? So Austin started with normativity and Hart with validity, what difference does it make? The difference may seem subtle but I think it is important for understanding the path of analytic jurisprudence in the last fifty years. Hart aimed to show that good analytic jurisprudence is sociology, because once he has elucidated the meaning of the relevant terms, there was no more "real" sociological work to be done. The gathering of empirical data will not add anything of value to what good analytic philosophy can do. ${ }^{22} \mathrm{I}$ do not know of any contemporary legal philosopher who accepts these views; but even though the particular account may not have contemporary defenders, this view has been instrumental in establishing the view that legal philosophy is a different, closed, even isolated domain. By answering the puzzle of the normativity of law "internally", i.e. by concep-

20 See Ryle, Gilbert, The Concept of Mind, London, Hutchinson, 1949, p. 16.

21 Contra Shapiro, Scott J., Legality, Cambridge, Harvard University Press, 2011 , p. 103. Shapiro accuses Hart of committing a category mistake by offering a reductive account of law's normativity. This claim is doubly odd: first, it is exactly the point of reductive accounts to explain one phenomenon in terms of another: if that were a category mistake, then no reductive explanation would be possible; second, as explained in the text Hart offers an explanation that, whatever its merits happen to be, clearly avoids the charge of category mistake.

22 Of sociology as done by sociologists Hart admitted he had always been "mistrustful". "Hart Interviewed: H. L. A. Hart in Conversation with David Sugarman", Journal of Law and Society, Vol. 32, 2005, 267-93, 289. 
tual analysis and armchair sociology, Hart has severed the link between jurisprudence and both normative philosophy and empirical inquiry at the point where one would have thought them most necessary. From this it is but a small step to the view more popular today that analytic jurisprudence and the social sciences have very little to say to each other because of their different concerns. ${ }^{23}$

It is not my intention to defend Austin's account. There is no doubt that his work has contributed to the isolationist trend in jurisprudence. But it is worth noting that even Austin's view is in some respect more "open" than Hart's in that it seeks to explain what law is from an external perspective. After Hart this is often taken to be a criticism of Austin, but we need to distinguish here between two senses in which a theory of law may be external. In one sense, it is external in that it ignores the attitudes of people engaged in law. Whether or not Austin is guilty of this charge, this sense of externality is not my concern here. Rather, my point is that Austin sought to give an account of law that does not follow existing linguistic usage, that does not follow the lawyers' perspective. Austin is quite clear that his account of what law is does not correspond exactly with linguistic usage: for the purposes of his account, he says, "whether ... an order [is] called a law, seems to depend on circumstances which are purely immaterial" (Province, p. 27). This is no coincidence. Such discrepancy follows inevitably from any account that does not start with legal validity, that does not seek to explain what law is by identifying what legal practitioners think law is. Whatever its other failings might be, this is an important advantage of Austin's account has over Hart's: it is only from an external perspective (in this sense) that one can that one avoids the trap of armchair (and hence, bad) sociology.

23 See Raz, Joseph, The Authority of Law: Essays on Law and Morality, 2nd ed. Oxford, Oxford University Press, 2009, pp. 44, 104-05; Shapiro, supra note 21, pp. 406-07 note 16. 


\section{The InVEntion of Legal Philosophy}

As I said above, before Hart and Austin philosophizing about law was never separated from normative questions. There was, however, another form of theoretical inquiry about law, the analysis of legal concepts. When this was confined to a particular legal system, this was simply part of the study of a particular area of law; when an attempt was made to generalize beyond a single legal system, this was termed "jurisprudence". Here, again, Hart and Austin take different sides. What Austin lectured his students about —what appears in his Lectures on Jurisprudence- is predominantly concerned with this sort of inquiry. There are fifty seven lectures in the posthumously published full set, and even this is only part of the larger project as Austin envisaged it. The Province of Jurisprudence Determined, the book that contemporary legal philosophers take some interest in, contains only six lectures, of which three have to do more with moral than with legal philosophy. This creates a somewhat skewed understanding of Austin's work and the place of the demarcation project within his overall interests.

Hart, then, has redrawn the borders of the province of jurisprudence from the way they were understood by Austin in two important respects. The first, the shift from a normativity-first account to a validity-first account, transformed the demarcation of a domain of inquiry (whatever happens to be positive law is the subject-matter of jurisprudence) to a very different substantive claim, put succinctly by John Gardner: "there is no such thing as nonpositive law." 24 Hart's commitment to this view is evident from the fact that under his framework the conceptual impossibility of non-positive law is true by definition. In the validity-first framework something can be law only if it is identified according to some test of validity. The content of the test can change from one legal system to another, but the existence

24 Gardner, John, "Some Types of Law", Douglas E. Edlin ed., Common Law Theory, Cambridge, Cambridge University Press, 2007, 51-77, p. 75. 
of the test itself is beyond question. And since the mark of a positive law is that it is (legally) valid, then the claim becomes impossible to refute. This is not Austin's view. As we have seen above, for him limiting jurisprudence to positive law was a demand of clarity of understanding, not a claim about what law is.

The second is the narrowing down of domain of jurisprudence. For Austin it included (one might even say consisted in) the analysis of the legal concepts. This is the material that makes up the bulk of his full Lectures and for which the material found in The Province was meant to serve only as boundary-setting introduction (Province, pp. 288-89). Following Hart the boundary-setting inquiry, now called the search for the "concept" or "nature" of law, has become the aim. Jurisprudence has now been reconceived as either the "descriptive" or conceptual attempt to answer the question "What is law?" or the normative inquiry into the question what the law (of contract, of crimes, of torts) should be. But the latter question was really now reconsidered as a question of moral philosophy about which the first, conceptual, inquiry had relatively little to contribute. The effect of this has been insufficient consideration of the extent to which the internal workings of the law take (its structure and organization, the content of its doctrines) may be relevant to an answer to the more general questions about law. Consequently, analytic jurisprudents paid little attention not only to legal doctrine, but also to legal history, economic theories of law, and even to political thought.

These two changes can be nicely demonstrated by considering the way the term "general jurisprudence" (or "universal jurisprudence") shifted its meaning. For Bentham it was used to describe those aspects of law true of all nations. It was under universal jurisprudence that "the censorial line", what we would now call normative jurisprudence, that is of greatest significance, because it is here that "there is the greatest room for disquisitions that apply to 
the circumstances of all nations alike". ${ }^{25}$ In other words, universal jurisprudence was primarily normative, because it was here that the ("descriptive") differences between legal systems become less significant. With Austin "general jurisprudence" has come to mean the analysis of the legal concepts that are found in all legal systems. As he put it, it was "principles abstracted from positive systems [that] are the subject of general jurisprudence" ("Study", p. 350); or in another formulation "General Jurisprudence" is "the science concerned with the exposition of the principles, notions, and distinctions which are common to systems of law" ("Study", p. 351). And as we have seen, after Hart the term general jurisprudence has come to have an even narrower meaning, one that in fact excludes much of what Austin considered as part of the subject in his lectures.

The Concept of Law, said Hart, was "written for lawyers and primarily had them in mind," 26 and it made the internal point of view - that of the lawyer who "accepts" legal rules as reasons for action- the central perspective of his account. At the very same Hart's approach to jurisprudence showed little interest in many of the questions that lawyers were interested in: investigation of legal concepts, the boundary between law and politics, different approaches to interpretation, the role of courts in society and much else. The result has been a form of inquiry that seeks to explain a social practice in the way it is understood from the eyes of those who participate in it, but does so by drawing on the methods of philosophy. (This point illustrates in another way in what sense Hart attempted to do philosophy and sociology at the same time.)

When presented in this way it is not hard to see why this effort was bound to fail right from the start: since lawyers did not concern themselves much with the question of the nature of law, then an account that sought to build on their attitudes was bound to have little to work with and not be

25 Bentham, Introduction, supra note 10, p. 295.

26 "Hart Interviewed", supra note 22, p. 291. 
very enlightening. And yet, this approach has prevailed and has had enormous influence. (It is an interesting question, but one that I cannot address here, why this happened.) As a result of Hart's inversion of normativity and validity and the primary place he has given to the question of validity, one can nowadays discern two ways in which the broadly Hartian approach to legal philosophy has been further developed. One approach, concerned with an answer to the question "What is law?", focuses more on identifying the existence conditions of law by building on a positivist account of legal validity. The other focuses more on the question of normativity and attempts to improve upon Hart's practice theory of rules with an alternative "positivist" (i.e., one that does not rely on morality) answer.

As a result we can distinguish between two versions of legal positivism, or as I would prefer to put it, two views on the domain of legal positivism: one could be a positivist with regard to validity, and one could be a positivist with regard to the explanation of law's normativity. Unfortunately, while some self-styled positivists focus more on validity and others on normativity, the two versions of positivism are rarely treated separately. Perhaps this is because Hart never distinguished between the two domains, possibly because he never clearly separated between the questions of validity and normativity and tried to be a positivist in both domains. Be that as it may, it is important to see that they may represent two different issues and it is not obviously clear that they easily go together: as the example of Austin shows in some ways the two issues may reflect two conflicting approaches to legal theory; and in a different way the work of Joseph Raz also highlights the separation of these issues, as Raz is a positivist on the question of validity but a non-positivist on the question of normativity. The significance of this point goes well beyond the question of "correctly" classifying the ideas of various legal theorists as "positivist" or not. I believe that the failure to see clearly the distinctness of these issues has been detrimental to much 
"positivist" work. Potentially valuable contributions to the question of normativity are undermined by being embroiled with unsuccessful attempts to defend legal positivism in the domain of validity or, worse, with the fruitless (and hopeless) effort to answer the question "What is law?" as a conceptual question to which legal philosophers can meaningfully contribute.

\section{CONCLUSion: Hart's Faustian Bargain}

Elsewhere I argue that contemporary positivists' appropriation of Thomas Hobbes and Jeremy Bentham to the positivist fold is misleading. ${ }^{27}$ In this essay I have argued that in some sense this is true even of Austin. Although Austin's work is clearly closer in spirit to that of contemporary legal positivists, there are important differences between his account of law and that of his followers. The point, however, is broader and more general than Austin exegesis. I said at the beginning of this essay that one of the problems with contemporary jurisprudence is that there seems to be little awareness of work in the field prior to 1961. I hope it is clear now why this is so. It is not because there were no useful contributions by philosophers to thinking about law before Hart. I assume that even Hart's followers would admit that he was not nearly as original as were, say, Hobbes or Hume. But if there is today relatively little interest at their work on law (compared with the amounts dedicated to Hart in both writing and teaching), it is because by contemporary standards they were not doing what counts as legal philosophy. Their work was perhaps an important stepping stone -one that deserves an appreciative paragraph (or footnote), but not careful study- in the way to the creation of legal philosophy properly so

27 See Priel, Dan, “Jurisprudence between Science and the Humanities", Washington University Jurisprudence Review, Vol. 4, (forthcoming 2012), available at http://ssrn.com/abstract=1566858; Priel, Dan, "Towards Classical Legal Positivism" (unpublished manuscript), available at http://ssrn.com/abstract $=1886517$. 
called. It is for this reason that I said in the beginning that in a sense contemporary legal philosophy is a new subject, one that did not exist before The Concept of Law.

The transformation Hart brought to jurisprudence is this: one can have a subject called "legal philosophy" as distinct from both law and political philosophy, but it will be possible to keep this subject alive only by keeping out artificially, as not part of the subject, the kind of problems and questions that challenge this demarcation. Thus, by definition, differences between legal systems that might presumably be shown to be a challenge to the notion of "general jurisprudence" (in its contemporary sense) are ruled out as the domain of sociology (and as such irrelevant); and the separation of legal philosophy from political philosophy again guarantees that any attempt to show that the political foundations of legal systems result in fundamentally different concepts of law is also declared off-limits and can thus be ignored.

All this comes at a price: legal philosophy is alive but it owes whatever life it currently has to a kind of Faustian bargain: Legal philosophy will continue to live as a distinct discipline, but the price for being alive is that it will be so separate from other disciplines to seem to be existing in its own separate world. Academic lawyers, even those with theoretical inclinations and interests rarely see the point of many jurisprudential debates. Legal philosophers, aware of this, sometimes respond with a sneer: other academic lawyers are not smart and sophisticated enough, or sufficiently well-read in philosophy, to understand the issues legal philosophers are dealing with. ${ }^{28}$

28 Most of these comments, naturally, do not make it to print. But see, Coleman, Jules L. \& Leiter, Brian, "Determinacy, Objectivity, and Authority", in Andrei Marmor (ed.), Law and Interpretation: Essays in Legal Philosophy, Oxford, Clarendon Press, 1995, 203-78, pp. 204-05, where it can be glimpsed; see also Waldron, Jeremy, "Legal and Political Philosophy", Jules Coleman \& Scott Shapiro (eds.), The Oxford Handbook of Jurisprudence and the Philosophy of Law, Oxford, Oxford University Press, 2002, 352-81, pp.374-75, who mentions (but does not endorse) these attitudes. 
But the truth is that moral and political philosophers, against whom it is much harder to make these claims, are not much interested either and (this is something I have personally heard from more than one of them) do not seem to understand the point of what legal philosophers do.

For all these reasons my ultimate assessment of The Concept of Law and its legacy are largely negative. Is there nonetheless nothing to be salvaged from it? I pointed out earlier that there are in fact two distinct strands that purport to follow on Hart's work, one that focuses more on the question of validity, the other that looks more to normativity. If legal positivism has any plausibility or significance it is, I think, only with regard to the second question. Hart's positivist approach to the question of normativity is also seen where he follows, explicitly albeit cautiously, on the footsteps of Hobbes and Hume in attempting a "positivist" answer to questions of normativity of morality (Concept, pp. 193-200). It is these ideas, which sit rather uneasily with other parts of the book, but which have the strongest ties with work of theorists now considered founders of legal positivism, ${ }^{29}$ that I think (or at least hope) should prove the longest lasting contribution of Hart's work in analytic jurisprudence.

29 Cf. Priel, “Towards Classical Legal Positivism”, supra note 27. 